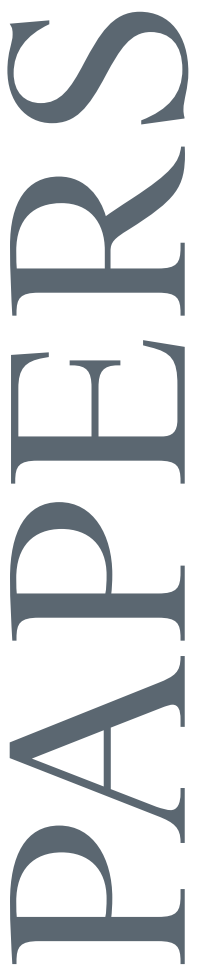

EAST-WEST CENTER WORKING PAPERS

Innovation and Economic Growth Series

No. 14, October 2018

North Korea: Sanctions, Engagement, and Strategic Reorientation

Marcus Noland

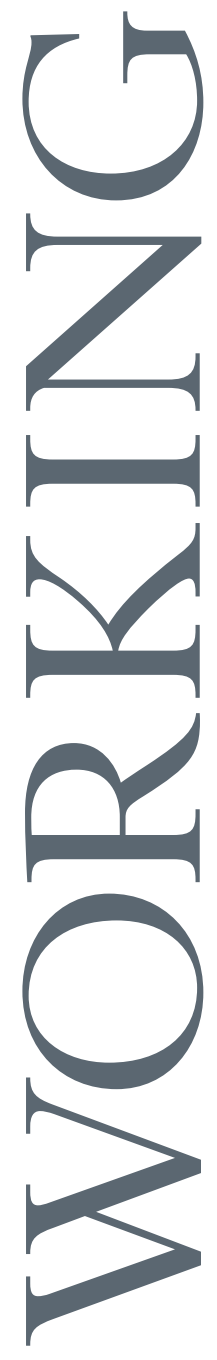

王 EAST-WEST CENTER 


\section{North Korea: Sanctions, Engagement, and Strategic Reorientation}

Marcus Noland

Marcus Noland is executive vice president and director of studies at the Peterson Institute for International Economics. He is also

East-West Center Working Papers is an unreviewed and unedited prepublication series reporting on research in progress. The views expressed are those of the author and not necessarily those of the Center. East-West Center Working Papers are circulated for comment and to inform interested colleagues about work in progress at the Center.

Working Papers are available online for free at EastWestCenter.org/ewcworkingpapers.

The East-West Center promotes better relations and understanding among the people and nations of the United States, Asia, and the Pacific through cooperative study, research, and dialogue. Established by the US Congress in 1960, the Center serves as a resource for information and analysis on critical issues of common concern, bringing people together to exchange views, build expertise, and develop policy options.

The Center's 21-acre Honolulu campus, adjacent to the University of Hawai'i at Mānoa, is located midway between Asia and the US mainland and features research, residential, and international conference facilities. The Center's Washington, DC, office focuses on preparing the United States for an era of growing Asia Pacific prominence.

The Center is an independent, public, nonprofit organization with funding from the US government, and additional support provided by private agencies, individuals, foundations, corporations, and governments in the region. adjunct senior fellow in the Research Program at the East-West Center.
This paper was prepared for the Asian Economic Policy Review conference, Tokyo, Japan, 20 October 2018. I would like to thank Soyoung Han for research assistance and Kent Boydston, Bill Brown, and Andrew Wolman for helpful comments on an earlier draft.

\section{E}




\title{
North Korea: Sanctions, Engagement and Strategic Reorientation
}

\author{
Marcus Noland \\ East-West Center and the Peterson Institute for International Economics
}

\begin{abstract}
This paper examines the roles that sanctions, and inducements might play in resolving the North Korea problem. It finds that while the "maximum pressure" narrative is plausible, the evidence to substantiate it is thin. Likewise, the North Korean regime is aware of the potentially constraining (or even destabilizing) political implications of cross-border economic integration and has acted to structure engagement in ways to blunt its transformative impact. Maximizing the transformative possibilities of engagement will require conscious planning by North Korea's partners. Multilateral guidelines and voluntary codes on corporate conduct could be used to anchor this process, but they will only be effective if there is greater political commitment to such norms than has been witnessed to date. Without such commitments, engagement risks enabling North Korea's doctrine of the parallel development of weapons of mass destruction and the economy.
\end{abstract}

JEL Codes: J8, F51, J47, P33

Keywords: North Korea, sanctions, labor standards, voluntary codes, special economic zones

19 September 2018

Paper prepared for the Asian Economic Policy Review conference, Tokyo, Japan, 20 October 2018. I would like to thank Soyoung Han for research assistance and Kent Boydston, Bill Brown, and Andrew Wolman for helpful comments on an earlier draft. 
In 2017, North Korea conducted a nuclear weapon test and multiple intercontinental ballistic missile (ICBM) tests. What followed in 2018 was a flurry of diplomatic activity, culminating in the first ever meeting of the North Korean and American heads of state in June.

There are two non-mutually exclusive explanations for this turn in events. The "maximum pressure" narrative emphasizes the role of economic sanctions, tough talk, and military exercises in bringing North Korea to the negotiating table; the other emphasizes North Korean agency and a strategic shift initiated by North Korean leader Kim Jong-un. Sanctions alone are unlikely to stop North Korea's development of weapons of mass destruction and their missile delivery systems, however, and even if it is pressure that has brought North Korea to the negotiating table, then inducements are likely to be a component of any permanent resolution of the North Korea problem.

Similarly, economic engagement alone is unlikely to wean North Korea off nuclear weapons. Even if the apparent willingness to enter negotiations over its military programs is fundamentally due to an autonomous change in North Korean attitudes, inducements are a tool to reinforce this shift and encourage faster, deeper movement in the desired direction. The nature of engagement matters, however, and thus far North Korea has successfully steered cross-border exchange toward modalities that are the least politically constraining for the regime. Effective transformative engagement, which might lock-in a permanent alteration in North Korea's military stance, will require careful design on the part of North Korea's foreign counterparts.

This paper examines the roles that sanctions, and inducements might play in discouraging North Korea's development of weapons of mass destruction and encouraging more peaceable and conciliatory relations with its neighbors. It finds that while the "maximum pressure" story is plausible, the evidence to support it is thin. Likewise, the North Korean regime is aware of the potentially constraining (or even destabilizing) political implications of cross-border economic integration and has acted to structure engagement in ways to blunt its transformative implications. Maximizing the transformative impact of engagement will require conscious planning by North Korea's partners. Multilateral guidelines and voluntary codes on corporate conduct could be used to anchor this process, but they will only be effective if there is greater political commitment to such norms than has been witnessed to date. Without such commitments, engagement risks enabling North Korea's doctrine of the parallel development of weapons of mass destruction and the economy. 


\section{Sanctions}

If North Korea traded as if it were a "normal" country, gravity modeling indicates its largest trade partners would be South Korea, China, Japan, the United States (US), and Russia (Noland 2014). Roughly speaking, South Korea, Japan, and the United States ban trade with North Korea, and trade with other countries is constrained by a series of nine United Nations Security Council resolutions (UNSCRs) adopted since 2006 (table 1).

The sanctions embodied in the first five resolutions were largely defensive in nature, focused on disrupting the North Korean military program. Reports produced by a Panel of Experts established under UNSCR 1718 (2006) document some success in frustrating North Korean arms exports. There is less evidence of success in impeding the importation of inputs to the weapons programs, at least in the public domain.

UNSCR 1718 also banned the export of luxury goods to North Korea in attempt to punish the regime elite without adversely affecting common people. The resolution did not specify a definition of "luxury good," however, (this was left up to individual countries), and China, North Korea's largest trade partner did not publish a list. As shown in figure 1 when the Australian and Japanese luxury good lists are applied to Chinese trade data, luxury goods exports rise almost monotonically through multiple UNSCRs. ${ }^{1}$ Econometric modeling also fails to detect any rise in a risk premium on broader trade with North Korea following the first UNSCRs. Indeed, the trade equations reveal that there was an increase in the propensity to trade with China following the UNSCRs, presumably as exporters in other countries grew warier (Haggard and Noland 2017).

Sanctions tightened considerably beginning with UNSCR 2321 (2016) and today, the multilateral sanctions are comprehensive, covering roughly 90 percent of North Korean trade, as well as constraining investment and financial transactions. But the resolutions have not had strong enforcement provisions, and reports by a Panel of Experts document trading abetted by sophisticated sanctions evasion efforts, as well as lax enforcement by some UN members.

\footnotetext{
${ }^{1}$ In contrast, luxury goods exports from the EU and Russia to North Korea dwindled following UNSCR 1716.
} 
That said, three UNSCRs adopted in late 2017 contributed to a significant decline in North Korea's trade (figure 2). (North Korea does not report trade statistics. China accounts for approximately 90 percent of North Korea's recorded trade, and the Chinese data can be taken as a convenient representation of the North's overall trade.) According to Chinese statistics, in early 2018 bilateral trade fell by more than 50 percent year-over-year. One would expect the economy to be reeling from a sanctions-derived shock of this magnitude, a development which would support the "maximum pressure" narrative of North Korean coming to the negotiating table in 2018 in response to economic dislocation brought about by tightening sanctions.

Conventional indicators of distress - the black-market exchange rate and the price of rice - have been stable, however, undercutting this narrative (figure 3). There are a variety of hypotheses that could explain the falling trade/stable prices conundrum. The first is that the price data, collected by groups supported by the South Korean government are inaccurate - sanctions are having the expected effect, but the dissemination process has been politicized by a "progressive" government in Seoul that does not want to feed the "maximum pressure" narrative of the Trump Administration in the US. Visitors to North Korea corroborate that prices are in fact roughly stable, however.

An alternative explanation is that the trade data are misleading - the actual trade shock has not been as big as the published data would suggest. This might be the case if China, which accounts for the bulk of North Korea's trade was misreporting (as it has at times in the past) or that there are materially relevant levels of smuggling not captured in the recorded data. ${ }^{2}$

Another possibility is that the data are correct, but the economy is cushioned-to paraphrase the late Herb Stein, something is "sustainable until it is not." One can think of four cushions. The first is stockpiling. It appears that understanding that its actions in 2017 were likely to result in tightened sanctions, the North Korean government pre-emptively imported oil

${ }^{2}$ Press reports suggest that such smuggling has often taken the form of representing goods of North Korean origin such as fish or coal as being from other, non-sanctioned, sources. See, for example, "Another vessel suspected of carrying N. Korean coal found," Dong-A Ilbo, 8 August 2018. http://english.donga.com/3/all/26/1417639/1 Accessed 8 August 2018. 
and food. ${ }^{3}$ Release of stockpiled inventories could keep prices for commodities stable and forestall sanctions-related panic.

A second possible source of support would be reserves. There is no consensus as to what kind of monetary reserves the North Koreans can draw upon, though some estimates put the figure in the billions of dollars (cf. Zang 2013). Perhaps if these reserves are held in Chinese RMB or Russian rubles rather than US dollars or EU euros, they could be kept off the radar. Similarly, North Korea has long been involved in illicit activities, cybercrime appears to be the emerging growth sector. North Korea may also have access to underappreciated sources of foreign support. The September 2012 scientific cooperation agreement with Iran the signing of which roughly coincided with the macroeconomic stabilization of North Korea, as well as Russian and Chinese aid, are the most obvious possibilities. However, even if North Korea had access to unobservable revenue streams to finance imports, one would expect to see it manifested in the trade data. The capacity to finance imports is meaningless if the goods cannot be imported.

Finally, it is possible that the imposition of hard budget constraints on state-owned enterprises, whose wage bills were a significant component of monetary growth, was implicitly a monetary policy shock that effectively put North Korea on a kind of quasi-currency board exchange rate system. In this case, the economy could be contracting but the exchange rate would remain stable.

The magisterial work of Hufbauer et al. (2008) establishes that for sanctions to have a high likelihood of inducing desired change in the target country's behavior, three conditions should be met: the target should be small and weak; the targeted policy or behavior should not be a core political goal of the regime; and the sanctioning coalition should be universal or nearuniversal. Haggard and Noland (2017) extend this analysis by observing that the internal political economy of the target state matters as well: authoritarian states, of which North Korea is an exemplar, are uniquely suited to resist sanctions, insofar as they possess a unique capacity to repress discontent associated with sanctions and channel sanctions-derived rents to favored constituencies in the desired direction.

\footnotetext{
${ }^{3}$ Marcus Noland, "Slave to the Blog: The Rising Tensions Edition," Witness To
} Transformation, 31 May 2017. https://piie.com/blogs/north-korea-witness-transformation/slaveblog-rising-tensions-edition Accessed 13 August 2018. 
Sanctions alone are unlikely to end the North Korean nuclear program. While they may have played a role in bringing North Korea to the negotiating table it is impossible to substantiate the claim that they were decisive. And in some sense these considerations are moot-since Kim Jong-un agreed in March 2018 to meet with Donald Trump, anecdotal evidence suggests that China - North Korea's dominant trade partner-has eased up on sanctions enforcement. The South Korean government in Seoul, in the wake of two 2018 North-South summits, and the June 2018 Trump-Kim summit, is clearly looking for ways to engage, and in the Security Council, China and Russia have attempted to formally relax sanctions but were stymied by the US.

The bottom line is that the "maximum pressure" moment has passed, and it will take time and serious North Korean provocations to rebuild the diplomatic support for significant multilateral sanctions.

\section{Inducements}

Well, if sanctions are not the explanation for the intensified diplomatic activity, how about North Korean agency? Something did appear to change in North Korea in 2018: Kim Jong-un in effect renounced the byungjin line of parallel development of nuclear weapons and the economy, indicating that the focus would shift to the economy. ${ }^{4}$ The previously forbidden word "reform" began to appear in the official discourse, and Kim Jong-un's onsite visits emphasized economic over military venues. The North Koreans initiated limited dismantling of military facilities while apparently continuing other efforts in the nuclear and missile fields.

The notion of a strategic shift has surface plausibility: Kim Jong-un is in his thirties, and if he wants to die peacefully in his bed as the leader of North Korea, he will need to make changes. Playing out the string like his father did does not appear to be a viable option. And as a small, and potentially, open, economy, external economic relations will be crucial. So, if these developments reflect a nascent strategic shift by the North Koreans, then the appropriate response by the outside world is to engage and try to reinforce this development.

${ }^{4}$ Ankit Panda, “The Trump-Kim Summit, North Korea's 'New Strategic Line,' and Pompeo's 'Bold Approach' 2.0,” The Diplomat May 23, 2018 https://thediplomat.com/2018/05/the-trump-kim-summit-north-koreas-new-strategic-line-andpompeos-bold-approach-2-0/ accessed 30 July 2018. 
Engagement strategies can be thought of as falling into two broad categories: those operating through quid-pro-quo inducements, and those aimed at achieving policy goals through the long-run transformation of the target state.

The first approach operates on the notion of reciprocity: the outside coalition provides inducements to the target country for policy change, withholding payment if the desired behavioral change does not occur. Examples include the long history of "food for talks," in which the US provided humanitarian assistance to North Korea as an inducement for North Korean participation in missile and nuclear negotiations (Haggard and Noland 2017 table 4.5), and even more dramatically, the policy of South Korean President Roh Moo-hyun, which was essentially policy of appeasement aimed at buying peaceful coexistence while the Roh government focused on domestic reforms (Ra 2013).

This approach is subject to classic bargaining problems. Do inducements come in advance of the quid-pro-quo, with moral hazard risk, or only ex-post, with standard credible commitment problems? Such considerations are particularly acute with respect to dismantling "lumpy" fixed investments in a nuclear program that exhibit significant irreversibility. Furthermore, this approach faces the same sorts of collective action and coordination problems that plague sanctions.

So, what about the more ambitious transformative approach? It has an intellectual history extending back at least to Frédéric Bastiat, Norman Angell, and the $19^{\text {th }}$ century notion of "liberal peace." More recently such approaches can be seen in American President Richard Nixon's détente policy toward the Soviet Union, West German Chancellor Willy Brandt's Ostpolitik approach to relations with East Germany, and most saliently, South Korean President Kim Dae-jung's Sunshine Policy of inter-Korean relations, which derived its name from the Aesop Fable of the Sun and the Wind, in which the Sun wins a bet with the Wind by successfully inducing a traveler to remove his coat by providing warmth.

The idea is that economic engagement will alter internal coalitional alignments, strengthening actors with a stake in maintaining pacific external relations, and ultimately contributing to less bellicosity by the target state. In this conception, engagement is an instrument of transformation, a means to an end. Differing modalities of engagement, which embody varying degrees of transformative potential matter critically. But this approach faces a fundamental endogeneity problem: Incumbent coalitions in the target state that are averse to 
openness recognize the "poison pill" or "Trojan Horse" nature of engagement, and not only have capacity to resist sanctions, but will also seek to control the nature of cross-border flows precisely to maximize regime gains and limit transformation.

\section{Purposeful Engagement}

It is commonly conjectured that increased cross-border exchange will contribute to an improvement in the North Korean economy, ultimately promoting a lessening of internal repression and a moderation of the country's foreign policy. But this argument often rests on unexamined assumptions about the nature of economic engagement, specifically the extent to which engagement fosters market-orientation and reduces direct state control over the economy. It is possible that by giving rise to a middle class, providing influential factions an enhanced stake in external economic relations, and/or by strengthening interest groups within the polity that have such stakes, an expansion of cross-border economic integration could generate the desired alteration in state preferences and behavior. But it is also the case that the incumbent power structure may also understand the implications of such processes and act to squelch their impact.

How such exchange develops in practice reflects the outcome of bargaining between North Korea and its partners. One can imagine that from a North Korean standpoint, the objective is to obtain revenue with minimal changes in internal practices and associated risks to political stability. From this perspective, the preference ranking over modalities of engagement runs from

- $\quad$ Straight cash payments, to

- $\quad$ Airline overflight rights, which generate revenue but involve no contact with the North Korean public, to

- $\quad$ Pipelines and railroads, which generate tariff revenue with minimal exposure of the public to foreigners, to

- $\quad$ Enclaves, such as the Kaesong Industrial Complex (KIC) and the Mt. Kumgang tourism project, which have been central to South Korea's interaction with North Korea, and involve limited, controlled interaction between North Korean citizens and foreigners, to 
- $\quad$ More decentralized forms of exchange, such as exhibited in dealings with Chinese traders and investors.

In the case of North Korea, where historically the economy was centrally planned and external relations highly politicized, it is perhaps not surprising that a comparison of the modalities of exchange between China and South Korea reveal significant differences. Chinese exchange with North Korea can be grouped into three broad categories: aid; state-directed trade and investment, in where the Chinese state provides a significant subsidy component; and decentralized exchange with little or no state support. Contrary to the popular image, most Chinese enterprises doing business in North Korea do so without state support. Regardless of their specific legal status in China, these are profit-seeking enterprises, transacting on marketconforming terms. They are not charitable enterprises: if they cannot earn profits, they withdraw from doing business with North Korea (Haggard, Lee, Noland 2012; Haggard and Noland 2017; Haggard and Noland, 2018).

Business is transacted in an extraordinarily weak institutional environment where corruption is endemic and dispute settlement mechanisms are weak. Firms rely on personal ties for identifying counterparties and resolving disputes. Little trust, as proxied by willingness to extent credit or relaxed payment terms to counterparties, is evident. Survey data reveal that these Chinese enterprises fear seizure of assets and consequently favor trade over investment in North Korea which is associated with expropriation risk. The upshot is that these institutional weaknesses penalize the country: if they were addressed, the North's globalization could proceed on more favorable terms.

In terms of its transformative potential, engagement with China could potentially have two positive effects. First, rising incomes may place greater demands on the North Korean regime (for improved access to information, for example) and given the isolation of the North Korean population, contact with Chinese business people could have some educational effect. But these effects should not be exaggerated. When they invest abroad, Chinese enterprises have a reputation for contributing little to host communities, bringing with them their own workers for example, a practice that has at times irritated local sensibilities and in democracies become a subject of contestation in local politics (Hendrix and Noland 2014). And, if anything, the government of China is likely to cooperate with the North Korean regime in trying to limit the transformative effects of engagement. 
From the standpoint of the North Korean regime, engagement with South Korea is potentially more threatening than involvement with China, and unsurprisingly the modalities of exchange that have emerged between these two countries differ. South Korea is North Korea's natural trade partner, and prior to the imposition of sanctions, South Korea accounted for a significant share of North Korea's trade and investment. If sanctions were relaxed or lifted, one might expect a significant expansion of exchange, and that engagement with the dynamic, capitalist South could be a catalyst for change. But the historical record does not provide unambiguous support for this proposition.

The history of North-South relations has given rise to a situation in which exchange occurs through three quite distinct modalities. When cross-border integration began in the 1990s, while some trade (mainly the importation of North Korean natural resource products) took the form of arm's-length transactions between unrelated entities, most trade took the form of processing-on- commission (POC) relations. Under this arrangement, South Korean firms shipped inputs to North Korea for assembly by North Korean partners, with the finished products re-exported for sale in South Korea or other third country markets. A typical example would involve South Korean garment manufacturers transshipping cut cloth, buttons, and thread through China to North Korea, where the components would be sewn into shirts and then reexported back through China for sale outside North Korea. ${ }^{5}$

A third modality of exchange subsequently developed at the Kaesong Industrial Complex (KIC). The zone, which opened in December 2004, sits just north of the North-South border and is easily accessible from Seoul. Firms in KIC were engaged in processing and assembly activities. Inputs were sourced from South Korea, transported to KIC, fabricated into finished products by North Korean workers, and then transported back to South Korea for sale there or in third-country markets. At its peak, firms operating in KIC employed more than 50,000 North Korean workers, and there were grand plans for expansion.

${ }^{5}$ In May 2010, South Korea banned POC trade as part of a sweeping sanctions package undertaken in response to a North Korean attack on a South Korean naval vessel. Much if not all of this trade was re-flagged as Chinese trade, either by South Korean owners transferring legal control to offices in China as a sanctions evasion measure, or by selling their businesses to Chinese producers. 
There is reason for skepticism about the KIC model. A comprehensive global review of SEZs undertaken by the World Bank found that they seldom worked, in the sense of achieving sustainability of a commercial basis - these projects were often initiated for political theatre or prestige reasons, and usually failed due to insufficient policy commitment on the part of the host government (Farole 2011). Indeed, the industrial park became a political football: it was closed by the North Koreans in a diplomatic dispute in April 2013 but re-opened in September 2013. South Korea "suspended" operations in 2016 in response to North Korea's fourth nuclear test and subsequent missile test. The enclave remains closed at this writing.

KIC required considerable public-sector support from South Korea, both in terms of infrastructure investment as well as indirect public subsidies to firms operating there (Haggard and Noland 2017). This operating model, which involves elements of public guarantees and subsidies, is presumably incompatible with UNSCR 2321 calling its future into doubt.

Financial terms on which these exchanges occurred indicate that the activity at KIC, undertaken with considerable South Korean government support, were the least risky, followed in terms of increasing risk, by POC exchange, and arm's-length transactions (Haggard and Noland 2012). Given the differences in degree of exposure to the North Korean policy environment, it would be reasonable to expect that management and employment practices might vary across the three modalities as well. From a policy perspective the real question is how these alternative approaches might contribute to encouraging real institutional change in North Korea and shift the country's political economy in the desired direction. These effects could come through backwards and forwards linkages, technology transfer broadly defined to include management techniques, or policy learning in terms of generalizing or extending lessons derived from KIC to the broader North Korean economy.

The results reported here are derived from a March 2010 survey of 200 firms engaged in trade or investment in North Korea. ${ }^{6}$ At its peak in the late 2000s, roughly 400 South Korean firms were engaged in economic activities in the North outside of KIC; activity at Kaesong, which peaked in 2013 with 123 firms, declined afterward. At the time it was undertaken, the survey sampled more than half the universe of South Korean firms doing business in North

\footnotetext{
${ }^{6}$ Complete details are provided in Haggard and Noland (2012).
} 
Korea. ${ }^{7}$ While the survey itself is dated, its results can be interpreted as a reasonable snapshot of business practices at the time trade between North and South Korea was effectively terminated, and therefore the baseline for any resumption of business in a post-sanctions re-engagement.

The focus is on industrial relations as a barometer of transformative potential. Forty-six of the firms surveyed reported hiring North Korean labor. Most of these employers, 33 of 46 firms (72 percent), operated in the KIC, though not necessarily exclusively there. Eight firms (17 percent), engaged in POC trade outside the KIC. A handful of firms were engaged exclusively in arm's length importing or exporting, and one firm engaged in both arm's length importing and exporting activities.

It is important to draw an important distinction between South Korean firms that employ North Korean workers and those that actually hire North Koreans. Only one of the 46 firms reported hiring workers directly; the clear majority reported hiring via a North Korean government labor agency, and this was the almost exclusive means of hiring for operations in the KIC (table 2). ${ }^{8}$

When the South Korean employers were asked if they believed that their workers had to pay their North Korean counterparties bribes or kickbacks for the privilege of working for the South Korean employer, a plurality of firms responded negatively, though 60 percent of those obtaining their labor via North Korean counterparties (significant at the 1 percent level) believed this to be the case. When asked if they were required to employ members of the Korean Workers Party (KWP), most firms said no, though 27 percent of the firms operating in the KIC indicated that they were forced to employ KWP members. But these responses obscure the fact that the firms were not actually hiring; if North Korean entities were responsible for actual hiring decisions, then it is the policies of those hiring agencies, not the firms that is relevant.

${ }^{7}$ The firms constitute a cross-section of the North Korean economy. Nearly half (43 percent) were involved in textiles and apparel, followed by watches, parts and accessories (13 percent), natural resource products ( 9 percent), machinery, motors and parts (9 percent), and electronic parts (9 percent). Apart from the KIC, the respondent firms had operations in the capital city Pyongyang, and the provinces of North Hamgyong, North Pyongan, and Gangwon.

${ }^{8}$ The only other avenue of hiring that received a noticeable response was that North Korean partners supplied the workers (11 percent overall). This channel of hiring labor was correlated at the 1 percent level with firms engaged in arm's length transactions and those involved in the natural resources sector. 
When asked about wage rates, perhaps not surprisingly, the dominant response (83 percent overall, 94 percent within the $\mathrm{KIC}$, and 54 percent outside the KIC) was that wage rates were set by the North Korean government. ${ }^{9}$ Similarly, an overwhelming share of firms reported paying wages to the North Korean government and not the workers directly (93 percent overall, 97 percent in the KIC, and 85 percent outside the KIC), 4 percent reported paying directly to the workers, and one firm operating in the KIC said it both paid the government and paid the workers directly. These findings the underscore the critical point that the wage payment going to workers was unknown. ${ }^{10}$

There is some evidence of incentive pay (table 3). While most respondents indicated that they paid based on a set daily or hourly wage rate, 22 percent reported paying overtime, 15 percent reported paying a piecework rate, and 7 percent reported paying bonuses for exceeding production targets. Consistent with relatively greater regulatory oversight, and more direct North Korean government pecuniary interest, overtime was paid more frequently in the KIC (27 percent versus 8 percent outside the KIC), but piecework was more common outside the zone (12 percent inside the KIC versus 23 percent outside of it). Half the POC firms, and nearly half of the KIC operations, used some form of incentive pay. Yet as shown below, it appears that the incentive payments went to the North Korean counterparty: it is unclear how much, if any,

${ }^{9}$ Other responses included North Korean partners ( 9 percent overall, and 60 percent for the firms engaged in arm's length transactions), the South Korean government and supply and demand (4 percent each).

${ }^{10}$ The minimum wage in the KIC gradually increased over time, so that with overtime, workers were in principle receiving \$100-200 monthly. The North Korean government was thought to retain roughly 30-40 percent of this payment however, ostensibly to cover social security payments, transportation, and other in-kind benefits, and given that the state got a cut of the wages, it had a direct incentive to negotiate and enforce generous overtime bonuses. It is unclear how these overtime bonuses were shared between the workers and the state (if at all). Importantly, while South Korean firms paid in US dollars, North Korea paid the workers in North Korean won converted at the wildly overvalued official exchange rate. Evaluated at the more realistic black-market rate, North Korean workers may have been netting only a few dollars per month (if their won salaries were converted back to dollars at the black-market rate). Looked at from another perspective, market prices for rice were on the order of 4,000-5,000 won per kilo during this period, suggesting that monthly after-tax wages might purchase roughly 2-3 kilos of rice. These figures imply that the real wages of KIC workers were low, though there appears to have been no shortage of North Koreans willing to work on these terms. 
actually reached the workers, and if incentives were operating, they may have been operating indirectly via North Korean management. ${ }^{11}$

Given that wages were usually paid to the North Korean government, the firms hiring via the government were asked if they knew exactly how much money their workers were in turn receiving from the government. Most of the employers refused to answer the question. Of those that did, their responses split nearly evenly between those which said that they knew (21 percent) and those that did not (18 percent). In other words, only one in five firms indicated that they knew how much their workers were actually paid. Remarkably, none of the firms that reported paying piecework indicated that they knew how much the workers were paid - they simply paid their North Korean counterparty and left it at that. However, when asked the follow up question whether they believed that the government took a large amount of money that was supposed to go to their employees, a majority responded affirmatively (76 percent overall, 77 percent in the KIC, 71 percent outside the KIC). The implication is that those firms claiming to be paying piece rate wages could not know for sure if they actually were.

In short, hiring was largely via the North Korean government, which pre-screened the workers, set wage rates administratively, demanded payment in foreign currency, and absorbed the lion's share of wage payments. Operations in the KIC were more bureaucratized or controlled than activities outside the zone.

\section{Industrial Relations}

South Korean managers generally did not directly supervise North Korean workers. Supervision was normally done through a North Korean intermediary manager. This was true regardless of whether the modality was KIC, POC, or arm's length relationships. Some firms, however, did

${ }^{11}$ No firms reported paying tips. This result is amusing insofar as Choco-Pies, a South Korean snack similar to American Moon Pies, emerged as a kind of parallel currency in the city of Kaesong. Originally provided to workers as a snack, unable to vary wage rates or reward particularly productive workers, South Korean firms began using extra allocations of the snacks to lure workers away from their competitors. The North Korean government became sufficiently concerned over these developments that in November 2011, North Korean officials, the South Korean KIC management committee, and the employers agreed to rules to limit the distribution of the snacks. Choco-Pie rules were on the agenda when North and South Korea negotiated the re-opening of KIC after its closure in 2013. 
report that either their managers directly supervised North Korean workers or used both indirect and direct supervision. Direct supervision occurred more frequently outside of the KIC (15 percent). However, if one combines the firms that indicated that they used direct supervision with those that responded that they used both direct and indirect supervision, then the percentage in the KIC (42 percent) is nearly double that outside of it (23 percent). That is, firms outside the KIC tend to either supervise their workers directly or not at all; those inside the KIC also mostly do not directly supervise their workers, but if they did, it was in combination with North Korean management, perhaps reflecting greater regimentation within the KIC.

The lack of direct supervision appeared to come at a cost: most South Korean firms agreed that it was difficult to supervise North Korean workers, but this seemed to be a bigger issue at the KIC (statistically significant at the five percent level), where firms tended to rely on the intermediation of North Korean managers. Apparently, supervision via North Korean intermediaries was a highly imperfect substitute for direct supervision. This may have stemmed from the fact that the North Korean intermediaries were not individuals who are assigned to Kaesong because of any managerial expertise, but rather essentially played a political function; indeed, it is plausible that such intermediaries reduced the efficiency of Kaesong businesses, as has been reported anecdotally with respect to other foreign-invested businesses.

As figure 4 shows, relatively few firms acknowledged that workers complained about conditions in their South Korean-operated factories (15 percent overall, 18 percent in KIC, 8 percent outside the KIC). There was no correlation between direct supervision or the use of both direct and indirect supervision and responding that workers complained, i.e. the pattern of responses indicating a lack of complaints did not appear to reflect lack of familiarity or contact. In fact, large majorities indicated that they thought that their employees considered themselves lucky to be employed by South Korean firms ( 80 percent overall). This general acceptance of working conditions seems to have been borne out by low turnover rates: 76 percent of the respondents indicated that a benefit of hiring North Korean workers was that the percentage who quit was low (79 percent in the KIC, 69 percent outside the KIC).

When asked how they handled situations involving unsatisfactory or unnecessary workers, 28 percent responded that they had never confronted this problem, including half of the POC firms (table 4). For the POC firms which made piece-rate payments to their North Korean counterparties, this result may have reflected the internalization of the pecuniary incentive of the 
North Korean counterparty management to weed out unproductive workers. The counterparty took care of this function.

Among the firms that did acknowledge needing to dismiss workers, none said that they were able to do so without obtaining some kind of approval or permission. Most firms which reported making dismissals (77 percent) said that they had to get the permission of the North Korean labor agency to dismiss a worker. Ten percent said that they had to get permission from the KWP, and another 10 percent said that they had to get permission from their North Korean partner. One firm reported paying severance. Once dismissed, all but one firm reported that their method of replacement was to go back to either the state labor agency or their North Korean partner and ask for another worker.

Work stoppages were infrequent: most firms reported that they had not experienced strikes or work stoppages ( 83 percent overall, 88 percent in the KIC, 69 percent outside the KIC; 75 percent for POC firms, 60 percent for arm's length firms). Among those firms that had experienced labor unrest, there appeared to be no standard method of dispute resolution. Some in the KIC (though none outside of it) appealed to the South Korean government or the North Korean government. The POC firms that experienced strikes or work stoppages most often appealed to their Chinese office or a Korean Chinese intermediary for help. Other employers indicated no method of settling disputes at all. When the South Korean employers were asked if a benefit of hiring North Korean workers was that they were not unionized, 61 percent responded affirmatively (58 percent in the KIC, 69 percent outside the KIC). Eighty percent of the firms engaged in arm's length transactions agreed with this sentiment.

What is critical from the standpoint of transformative engagement is the dog that did not bark: There is little statistical correlation between direct supervision of workers and either knowledge of their working conditions or worker attitudes. Direct supervision of workers was uncorrelated with beliefs that workers had to bribe to obtain jobs, knowledge of the share of wage payments retained by the government, knowledge or worker complaints, or beliefs about their happiness. In fact, firms that directly supervised their workers were more likely to complain about inadequate skills.

\section{International Norms and Voluntary Codes}


The results of the previous section document labor practices that appear both exploitative and by limiting the extent North Korean workers are exposed to new ways of organizing work (or even exposure to South Korean managers) are consequently unlikely to generate the desired transformational effects. The questions then become are these conventions consistent with the international obligations of the governments of North Korea and potential investors, and are there mechanisms that could be used to encourage the adoption of more humane and potentially transformative practices?

North Korea is not a member of the International Labor Organization, and internationally recognized core labor standards such as the rights to associate, organize, and bargain collectively are notable in their absence. South Korea, China, Japan, the United States and other potential large investors are ILO members, however. Similarly, South Korea, Japan and the United States are members of the Organization of Economic Cooperation and Development (OECD) which has promulgated its Guidelines for Multinational Enterprises (OECD 2011), which obligate investors to ensure that North Korean workers are aware of their rights and how to exercise them. These countries, as well as China, are also members of the United Nations which has released a set of Guiding Principles for Business and Human Rights (United Nations, 2011). Finally, the South Korean government could extend regulation over its investors extraterritorially; indeed, the constitution of the Republic of Korea makes claims over the entire peninsula, raising the issue of the extent that South Korean firms investing in North Korea ought to be subject to "domestic" standards and regulations. To what extent, if any, is the behavior of foreign investors in North Korea constrained in principle, if not in reality, by these covenants?

A basic issue with both the UN and OECD approaches is that they are oriented toward prescribing behavior for multinational firms in an environment in which the host government is committed to upholding international norms, by facilitating the use of home country legal machinery in situations where host country institutions are weak. The problem with their application in the North Korean case is that it is not so much that private firms subvert the government's attempt to do the right thing, but rather the state opposes the international norms, and the investor stands to benefit.

So, for example, the OECD Guidelines state that investors should respect human rights "within the framework of internationally recognized human rights, international human rights obligations of the countries in which they operate" (OECD 2011 p.31), and then go on to 
reference "the International Bill of Human Rights, consisting of the Universal Declaration of Human Rights and the main instruments through which it has been codified: the International Covenant on Civil and Political Rights and the International Covenant on Economic, Social, and Cultural Rights" and the ILO principles (OECD 2011 p.32). North Korea is a state party to the International Covenant on Economic, Social and Cultural Rights. So for example, the covenant obligates states to ensure "Equal opportunity for everyone to be promoted in his employment to an appropriate higher level, subject to no considerations other than those of seniority and competence" (Article 7) —an obligation eviscerated by North Korea's songbun system of political classifications (Collins 2012) and the rights of citizen's to form and join trade unions of their choice and strike (Article 8). These provisions would seem to establish both the government of North Korea's obligation under its international commitments to ensure certain rights, and for employers to respect those rights. But the Guidelines go on to say that "obeying domestic laws is the first obligation of enterprises...in countries where domestic laws and regulations conflict with the principles and standards of the Guidelines, enterprises should seek ways to honor such principles and standards to the fullest extent which does not place them in violation of domestic law" (OECD 2011 p.17). In North Korea, the state's unwillingness to meet its international legal obligations would seem to emasculate any salutary impact of the OECD Guidelines. ${ }^{12}$

The UN's Principles face similar difficulties. The first foundational principle is that "States must protect against human rights abuse within their territory and/or jurisdiction by third parties, including business enterprises" (UN 2011 p.6). The text goes on to elaborate principles for constraining the operation of firms and ensuring that neither host nor sending state contributes to the denial of human rights, but in North Korea, the state itself is the problem, and the UN Principles do not address the obligations of firms in such environments. They do suggest, however, that at times states may need to consider extraterritorial application of the law.

${ }^{12}$ However, the guidelines also specify that adhering countries establish National Contact Points (NCPs). The NCPs are primarily oriented toward ensuring the implementation of the OECD guidelines within the host adhering country. They are also tasked, however, with supporting the implementation of the guidelines by home country entities in non-adhering countries (Noland 2014). Some have also suggested that ILO Convention No. 94 and Recommendation No. 84 concerning labor clauses in public contracts could be applicable. But neither North nor South Korea are signatories to this convention. 
This notion could be salient in the case of South Korea. It has generally applied its labor laws extraterritorially only when the complainant is a South Korean national working for a South Korean company overseas (Wolman 2013). However, Article 3 of the South Korean constitution declares that the territory of the Republic of Korea consists of "the Korean Peninsula and its adjacent islands" establishing a de jure presumption of territoriality (Article 103 of the North Korean constitution makes a mirror claim to the entire peninsula) and a de facto status of extraterritoriality. The South Korean constitution then goes on to elaborate several economic rights including Article 33, "To enhance working conditions, workers shall have the right to independent association, collective bargaining and collective action." Article 6a reads "Treaties duly concluded and promulgated under the Constitution and the generally recognized rules of international law shall have the same effect as the domestic laws of the Republic of Korea." To be clear, the labor rights provision has been violated for much of South Korea's history. But one could interpret these articles and other, similar, provisions together with South Korea's international law obligations as forming the constitutional basis for encouraging, if not requiring, South Korean firms to facilitate nationally and internationally labor rights in North Korea. For example, a pro-active South Korean government could attempt to negotiate amendment of the KIC labor law to incorporate the core ILO labor standards, including the right to freedom of association and collective bargaining, the right to strike, prohibition against sexual discrimination and harassment, and a ban on child labor. The government of North Korea would almost certainly reject such a request, but the actual outcome would be a function of bargaining.

The obstacle to the extraterritorial application of South Korean law is not the lack of legal foundations, it is that South Korea's diplomatic commitment to engagement with North Korea trumps labor rights concerns, together with the perception of South Korean firms that the North Korean status quo confers benefits. From the outset, the South Korean government does not request to address labor conditions. To date, there is no evidence that the South Korean government has undertaken any steps that would encourage or require its firms to abide by any standards whatsoever. ${ }^{13}$

${ }^{13}$ One avenue would be to expand the jurisdictional authority of the (South) Korean National Human Rights Commission to address labor rights abuses committed by corporations (Wolman 2012). At present, the Commission does not have the authority to investigate actions by corporations either within or outside South Korea, but expanding its remit would be consistent with practices elsewhere. 
The treatment of KIC-produced goods in free trade agreements can be read as implicit evidence of the attitudes of other countries. The South Korean request for goods produced in the KIC to be classified as "made in South Korea" and receive duty-free treatment was rejected by US and EU negotiators. The two sides ultimately adopted a face-saving gesture of creating binational commissions to study the issue with the tacit understanding that the US and EU would never agree to duty-free treatment under the current economic and political conditions prevailing in North Korea. Other free trade agreement partners-Singapore and India, for exampleacceded to the South Korean request (Song 2011).

That leaves private activism as a possible remedy. One possibility noted above would be to encourage the development of codes of conduct similar to that of the Sullivan Principles that were used in South Africa during that country's apartheid period for foreign companies investing in North Korea. ${ }^{14}$ Again, politics matter: the introduction and development of the Principles occurred symbiotically with a growing anti-apartheid movement, which included shareholder resolutions, divestment campaigns, and at the level of state and local governments in the US, selective purchasing policies with respect to government procurement. ${ }^{15}$ Growing frustration over the apparent lack of progress in South Africa led Sullivan in 1984 to expand the Principles, adding a provision committing signatory firms to "working to eliminate laws and customs that impede social, economic, and political justice." The following year, President Ronald Reagan issued an Executive Order requiring firms to abide by fair employment standards similar to the

14 The Principles are named after the Reverend Leon Sullivan who was appointed to the General Motors (GM) board in 1971, becoming the first African-American board member of a major US corporation. At the time, GM was the largest employer of non-white South Africans, and Sullivan used his position on the GM board to advocate for reform of the apartheid system. In 1977 he formulated what came to be known as the Sullivan Principles aimed at remediating racial discrimination in employment practices. Sullivan established an independent administrative unit to implement the principles and recruited the accounting firm Arthur D. Little Inc. to monitor implementation at the company level. This experience inspired other initiatives such as the MacBride Principles (in Northern Ireland), the Slepak Principles (Soviet Union), the Miller Principles (China and Tibet), the Malquiladora Standards of Conduct (Mexico), and the Ceres nee Valdez Principles (environment). See McCrudden (1999).

${ }^{15}$ So, for example, the State of Maryland adopted a policy that firms bidding for contracts in excess of $\$ 100,000$ had to certify that either they did no business in South Africa or adhered to the Sullivan Principles. 
Sullivan Principles, but this could not stem the tide, and in 1986 the US Congress passed sanctions legislation.

In a judicious assessment of the impact of the Sullivan Principles, McCrudden (1999) writes, "there is some indication that the Principles had several positive effects: first, that corporations found them useful by providing a focus for their social and political activities in South Africa; second, that the Principles brought about some changes in conditions for black workers which may not have otherwise have occurred; third, that the Principles led to increased funding by companies of social causes in the South African community, and fourth, that they may have increased pressure on government for the recognition of black trade unions, an important factor in the development of organized black politics. It is difficult, however, for the effect of the Principles to be distinguished from the effect of other similar activity, outside the context of the Principles, such as undertaken by other countries, or from larger political and economic forces operating at that time in South Africa" (page 177). One weakness of the monitoring and assessment process was that much of the benchmarking was on the input side (dollars spent on corporate social responsibility projects, for example) rather than on the output side where the companies might have had the most capability for making a difference (i.e. employment expansion, job training, upward mobility, and small-business development) (Sethi and Williams 2000).

In 1999 Sullivan and UN Secretary General Kofi Annan formulated the Global Sullivan Principles of Corporate Social Responsibility, an antecedent to the previously discussed UN Principles. However, unlike the UN Principles, and consistent with their origins as guidelines for corporate activity, the Global Sullivan Principles focus on firm, not state, behavior. They call for multinational companies to proactively advocate for universal human rights and the rights of their employees and avoid the loophole created by deference to local law that enervates the UN Principles and OECD Guidelines. But the impact of such voluntary codes is only as effective as the activism behind them. Such activism is inconceivable in the case of China, and to date the South Korean public has been largely content to turn a blind eye to labor practices in North Korea.

\section{Conclusion}


Two narratives, one emphasizing pressure primarily exerted through economic sanctions, and the other North Korea agency, have been offered to explain the surge in diplomatic activity on the Korean peninsula. The "maximum pressure" narrative is plausible but appears belied by fact. A shift in North Korean policy is plausible but essentially non-falsifiable.

In either case, the nature of engagement could be of critical importance. Most North Koreans are so isolated from the rest of the world that nearly any exposure to foreigners and new ways of doing things should be regarded as positive. But the North Korean regime appears to be cognizant of the transformative potential of engagement and has attempted to offset its impact. There is little hope that engagement with China will confer such transformative effects, except through the broadest, most indirect channel of raising incomes.

One might have higher hopes for South Korean involvement. Evidence of spillovers that proponents of engagement sometimes assert is not apparent, however. Neither the South Korean government nor its public has shown much stomach for using its interaction with the North strategically. Rather South Korea appears content with involvement largely limited to publicly supported enclaves operating in a highly controlled manner. Other investors such as the United States, Japan, and the European Union might have more progressive agendas but are not sufficiently involved to wield much influence over North Korean internal practices.

Although many outcomes are possible, unless North Korea's partners begin to emphasize more transformative approaches to engagement, the most likely result will be a sort of muddling through. Multi- and bilateral sanctions will not be removed, but enforcement will weaken, and countries will find work-arounds to re-engage with North Korea. ${ }^{16}$ North Korea will be accepted as a de facto nuclear state, much like Pakistan is. The country will have in effect resolved the contradiction embodied in the byungjin line.

Whatever the external environment, the North Korean leadership will have to manage internal stresses of economic, political, and social change. Success in muddling through is not guaranteed.

${ }^{16}$ For example, the government of South Korea has established a liaison office in Kaesong, and in its 2019 budget, greatly expanded funding for economic engagement, while cutting the allocation to support human rights by more than 90 percent. 


\section{Tables and Figures}

Table 1.

United Nations Security Council Resolutions on North Korea

\begin{tabular}{|c|c|c|c|c|}
\hline Resolution & Date & Trigger & Provisions & Sanctions \\
\hline $\begin{array}{l}\text { UNSCR } \\
1718\end{array}$ & $\begin{array}{l}14 \text { October } \\
2006\end{array}$ & $\begin{array}{l}1^{\text {st }} \text { nuclear } \\
\text { test }\end{array}$ & $\begin{array}{l}\text { DPRK to abandon its } \\
\text { nuclear and ballistic } \\
\text { missiles activities and to } \\
\text { return to the NPT and the } \\
\text { Six-Party Talks }\end{array}$ & $\begin{array}{l}\text { - Ban exports of heavy weaponry, } \\
\text { some materials and technologies, } \\
\text { and luxury goods to DPRK } \\
\text { Freeze financial assets of entities } \\
\text { supporting DPRK nuclear } \\
\text { programs }\end{array}$ \\
\hline $\begin{array}{l}\text { UNSCR } \\
1874\end{array}$ & $\begin{array}{l}12 \text { June } \\
2009\end{array}$ & $\begin{array}{l}2^{\text {nd }} \text { nuclear } \\
\text { test }\end{array}$ & $\begin{array}{l}\text { - Repeated provisions from } \\
\text { UNSCR } 1718 \\
\text { DPRK to join the } \\
\text { Comprehensive Nuclear } \\
\text { Test Ban Treaty }\end{array}$ & $\begin{array}{l}\text { - Expand arms embargo to imports } \\
\text { and exports of weapons } \\
\text { - Inspect DPRK cargo if needed } \\
\text { - Prohibit financial support for } \\
\text { DPRK except for aid purposes }\end{array}$ \\
\hline $\begin{array}{l}\text { UNSCR } \\
2087\end{array}$ & $\begin{array}{l}22 \text { January } \\
2013\end{array}$ & $\begin{array}{l}1^{\text {st }} \text { satellite } \\
\text { launch }\end{array}$ & $\begin{array}{l}\text { - States to monitor entities } \\
\text { related to the DPRK regime }\end{array}$ & $\begin{array}{l}\text {-Impose stricter sanctions based on } \\
\text { UNSCR } 1718 \text { and UNSCR } 1874\end{array}$ \\
\hline $\begin{array}{l}\text { UNSCR } \\
2094\end{array}$ & $\begin{array}{l}7 \text { March } \\
2013\end{array}$ & $\begin{array}{l}3^{\text {rd }} \text { nuclear } \\
\text { test }\end{array}$ & $\begin{array}{l}\text { - Condemn DPRK's uranium } \\
\text { enrichment }\end{array}$ & $\begin{array}{l}\text { - Limit DPRK regime from bulk } \\
\text { cash transfers and international } \\
\text { banking system }\end{array}$ \\
\hline $\begin{array}{l}\text { UNSCR } \\
2270\end{array}$ & $\begin{array}{l}2 \text { March } \\
2016\end{array}$ & $\begin{array}{l}4^{\text {th }} \text { nuclear } \\
\text { test and } 2^{\text {nd }} \\
\text { satellite } \\
\text { launch }\end{array}$ & $\begin{array}{l}\text { - States to end training of } \\
\text { DPRK nationals } \\
\text { - DPRK to abandon chemical } \\
\text { and biological weapons and } \\
\text { to act in accordance with } \\
\text { the Biological Weapons } \\
\text { Convention and the } \\
\text { Chemical Weapons } \\
\text { Convention }\end{array}$ & $\begin{array}{l}\text { - Expand the arms embargo to small } \\
\text { arms and light weapons } \\
\text { - Obligate inspections on cargo to } \\
\text { or from DPRK } \\
\text { - Freeze assets of North Korean } \\
\text { government and Worker's Party } \\
\text { entities associated with prohibited } \\
\text { activities }\end{array}$ \\
\hline $\begin{array}{l}\text { UNSCR } \\
2321\end{array}$ & $\begin{array}{l}30 \\
\text { November } \\
2016\end{array}$ & $\begin{array}{l}5^{\text {th }} \text { nuclear } \\
\text { test }\end{array}$ & $\begin{array}{l}\text { - States to downsize staff at } \\
\text { DPRK diplomatic missions } \\
\text { and consular posts }\end{array}$ & $\begin{array}{l}\text { - Prohibit DPRK from exporting } \\
\text { minerals, iron and iron ore, and } \\
\text { more } \\
\text { - Limit bank accounts held by } \\
\text { diplomats and missions } \\
\text { - Suspend scientific and technical } \\
\text { cooperation with DPRK }\end{array}$ \\
\hline $\begin{array}{l}\text { UNSCR } \\
2371\end{array}$ & $\begin{array}{l}5 \text { August } \\
2017\end{array}$ & $\begin{array}{l}\text { Two ICBM } \\
\text { tests }\end{array}$ & $\begin{array}{l}\text { - Reiterate its support for the } \\
\text { Six Party Talks } \\
\text { - North Korea to accede to } \\
\text { the Chemical Weapons } \\
\text { Convention }\end{array}$ & $\begin{array}{l}\text { - Prohibit North Korean exports of } \\
\text { coal, seafood, and lead } \\
\text { - Allow the UNSC to deny } \\
\text { international port access to vessels } \\
\text { violating UNSCR } \\
\text { - Ban countries from allowing in } \\
\text { additional North Korean laborers }\end{array}$ \\
\hline $\begin{array}{l}\text { UNSCR } \\
2375\end{array}$ & $\begin{array}{l}11 \\
\text { September } \\
2017\end{array}$ & $\begin{array}{l}6^{\text {th }} \text { nuclear } \\
\text { test }\end{array}$ & $\begin{array}{l}\text { - Reiterate its support for the } \\
\text { Joint Statement of } 19 \\
\text { September } 2005\end{array}$ & $\begin{array}{l}\text { - Ban North Korean textile exports } \\
\text { and natural gas imports } \\
\text { - Limit refined petroleum product } \\
\text { and crude oil imports } \\
\text { - Prohibit states from authorizing } \\
\text { North Korean nationals to work in }\end{array}$ \\
\hline
\end{tabular}




\begin{tabular}{|l|l|l|l|l|}
\hline & & & $\begin{array}{l}\text { their jurisdictions } \\
\text { Ban all joint ventures with DPRK } \\
\text { entities }\end{array}$ \\
\hline $\begin{array}{l}\text { UNSCR } \\
2379\end{array}$ & $\begin{array}{l}22 \\
\text { December } \\
2017\end{array}$ & $\begin{array}{l}\text { ICBM } \\
\text { launch }\end{array}$ & $\begin{array}{l}\text { - Acknowledge that DPRK } \\
\text { revenue from exports and } \\
\text { workers overseas contribute } \\
\text { to nuclear weapons and } \\
\text { ballistic missile programs }\end{array}$ & $\begin{array}{l}\text { Direct states to expel all North } \\
\text { Korean workers } \\
\text { Ban North Korean exports of food, } \\
\text { agricultural products, minerals } \\
\text { machinery and electrical } \\
\text { equipment } \\
\text { Ban North Korea from importing } \\
\text { heavy machinery, industrial } \\
\text { equipment and transportation } \\
\text { vehicles }\end{array}$ \\
\hline
\end{tabular}


Table 2.

Methods of hiring North Korean labor

\begin{tabular}{|c|c|c|c|c|c|c|c|c|c|c|}
\hline \multirow[t]{2}{*}{$\begin{array}{l}\text { NK Employee Hiring } \\
\text { Method }\end{array}$} & \multicolumn{2}{|c|}{ Total } & \multicolumn{2}{|c|}{$\begin{array}{c}\text { KIC } \\
(\mathrm{n}=33)\end{array}$} & \multicolumn{2}{|c|}{$\begin{array}{c}\text { Non-KIC } \\
(\mathrm{n}=13)\end{array}$} & \multicolumn{2}{|c|}{$\begin{array}{c}\text { POC } \\
(\mathrm{n}=8)\end{array}$} & \multicolumn{2}{|c|}{$\begin{array}{l}\text { Arms-Length } \\
\quad(\mathrm{n}=5)\end{array}$} \\
\hline & Frequency & $\%$ & Frequency & $\%$ & Frequency & $\%$ & Frequency & $\%$ & Frequency & $\%$ \\
\hline Directly & 1 & $2 \%$ & 0 & $0 \%$ & 1 & $8 \%$ & 0 & $0 \%$ & 1 & $20 \%$ \\
\hline $\begin{array}{l}\text { From a North Korean } \\
\text { government labor agency }\end{array}$ & 38 & $83 \%$ & 31 & $94 \%$ & 7 & $54 \%$ & 7 & $88 \%$ & 0 & $0 \%$ \\
\hline $\begin{array}{l}\text { Our North Korean } \\
\text { partners supply the } \\
\text { workers }\end{array}$ & 5 & $11 \%$ & 1 & $3 \%$ & 4 & $31 \%$ & 1 & $13 \%$ & 3 & $60 \%$ \\
\hline Other & 2 & $4 \%$ & 1 & $3 \%$ & 1 & $8 \%$ & 0 & $0 \%$ & 1 & $20 \%$ \\
\hline Total & 46 & $100 \%$ & 33 & $100 \%$ & 13 & $100 \%$ & 8 & $100 \%$ & 5 & $100 \%$ \\
\hline
\end{tabular}

Table 3.

Types of Payments to North Korean Workers

\begin{tabular}{|c|c|c|c|c|c|c|c|c|c|c|}
\hline \multirow{2}{*}{$\begin{array}{c}\text { Compensation } \\
\text { Methods } \\
\text { Practiced }\end{array}$} & \multicolumn{2}{|c|}{ Total $(n=46)$} & \multicolumn{2}{|c|}{$\begin{array}{c}\text { KIC } \\
(n=33)\end{array}$} & \multicolumn{2}{|c|}{$\begin{array}{c}\text { Non-KIC } \\
(\mathrm{n}=13)\end{array}$} & \multicolumn{2}{|c|}{$\begin{array}{c}\text { POC } \\
(n=8)\end{array}$} & \multicolumn{2}{|c|}{$\begin{array}{c}\text { Arms-Length } \\
(\mathrm{n}=5)\end{array}$} \\
\hline & Frequenc & $\%$ Total & Frequency & $\% \mathrm{KIC}$ & Frequency & $\%$ Non-KIC & Frequency & $\%$ POC & Frequency & $\begin{array}{l}\text { \% Arms } \\
\text { Length }\end{array}$ \\
\hline $\begin{array}{l}\text { Pay hourly } \\
\text { wages }\end{array}$ & 41 & $89 \%$ & 31 & $94 \%$ & 10 & $77 \%$ & 6 & $75 \%$ & 4 & $80 \%$ \\
\hline $\begin{array}{c}\text { Make piece- } \\
\text { work payments } \\
\text { to North Korean } \\
\text { labor }\end{array}$ & 7 & $15 \%$ & 4 & $12 \%$ & 3 & $23 \%$ & 2 & $25 \%$ & 1 & $20 \%$ \\
\hline $\begin{array}{l}\text { Make overtime } \\
\text { payments to } \\
\text { North Korean } \\
\text { labor }\end{array}$ & 10 & $22 \%$ & 9 & $27 \%$ & 1 & $8 \%$ & 1 & $13 \%$ & 0 & $0 \%$ \\
\hline $\begin{array}{c}\text { Make bonus } \\
\text { payments to } \\
\text { North Korean } \\
\text { labor }\end{array}$ & 3 & $7 \%$ & 2 & $6 \%$ & 1 & $8 \%$ & 1 & $13 \%$ & 0 & $0 \%$ \\
\hline
\end{tabular}

Note: Firms able to choose all compensation methods that apply. 
Table 4.

Dismissal and replacement methods for unsatisfactory North Korean workers

\begin{tabular}{|c|c|c|c|c|c|c|c|c|c|c|}
\hline \multirow{2}{*}{$\begin{array}{c}\text { Methods of Dealing } \\
\text { with Unsatisfactory } \\
\text { Workers }\end{array}$} & \multicolumn{2}{|c|}{ Total $(n=46)$} & \multicolumn{2}{|c|}{$\begin{array}{c}\mathrm{KIC} \\
(\mathrm{n}=33)\end{array}$} & \multicolumn{2}{|c|}{$\begin{array}{c}\text { Non-KIC } \\
(\mathrm{n}=13)\end{array}$} & \multicolumn{2}{|c|}{$\begin{array}{c}\text { POC } \\
(n=8)\end{array}$} & \multicolumn{2}{|c|}{$\begin{array}{l}\text { Arms-Length } \\
\quad(\mathrm{n}=5)\end{array}$} \\
\hline & Frequency & $\begin{array}{c}\% \\
\text { Total } \\
\end{array}$ & Frequency & $\begin{array}{c}\% \\
\text { KIC }\end{array}$ & Frequency & $\begin{array}{c}\text { \% Non- } \\
\text { KIC }\end{array}$ & Frequency & $\begin{array}{c}\% \\
\text { POC }\end{array}$ & Frequency & $\begin{array}{l}\% \text { Arms } \\
\text { Length }\end{array}$ \\
\hline Dismissal Methods & & & & & & & & & & \\
\hline $\begin{array}{l}\text { Made serverance } \\
\text { payment }\end{array}$ & 1 & $2 \%$ & 1 & $3 \%$ & 0 & $0 \%$ & 0 & $0 \%$ & 0 & $0 \%$ \\
\hline $\begin{array}{l}\text { Get permission from } \\
\text { North Korean labor } \\
\text { agency }\end{array}$ & 24 & $52 \%$ & 20 & $61 \%$ & 4 & $31 \%$ & 3 & $38 \%$ & 1 & $20 \%$ \\
\hline $\begin{array}{l}\text { Get permission from } \\
\text { North Korean partner }\end{array}$ & 3 & $7 \%$ & 1 & $3 \%$ & 2 & $15 \%$ & 1 & $13 \%$ & 1 & $20 \%$ \\
\hline $\begin{array}{l}\text { Get permission from } \\
K W P\end{array}$ & 3 & $7 \%$ & 3 & $9 \%$ & 0 & $0 \%$ & 0 & $0 \%$ & 0 & $0 \%$ \\
\hline $\begin{array}{l}\text { Get permission from } \\
\text { South Korean } \\
\text { government }\end{array}$ & 0 & $0 \%$ & 0 & $0 \%$ & 0 & $0 \%$ & 0 & $0 \%$ & 0 & $0 \%$ \\
\hline $\begin{array}{l}\text { Required no } \\
\text { permissions or } \\
\text { approvals }\end{array}$ & 0 & $0 \%$ & 0 & $0 \%$ & 0 & $0 \%$ & 0 & $0 \%$ & 0 & $0 \%$ \\
\hline $\begin{array}{l}\text { Replacement } \\
\text { Methods }\end{array}$ & & & & & & & & & & \\
\hline $\begin{array}{l}\text { Dismissed worker and } \\
\text { hired a new one }\end{array}$ & 1 & $2 \%$ & 1 & $3 \%$ & 0 & $0 \%$ & 0 & $0 \%$ & 0 & $0 \%$ \\
\hline $\begin{array}{l}\text { Dismissed worker and } \\
\text { asked North Korean } \\
\text { government labor } \\
\text { agency to supply new } \\
\text { one }\end{array}$ & 22 & $48 \%$ & 18 & $55 \%$ & 4 & $31 \%$ & 4 & $50 \%$ & 0 & $0 \%$ \\
\hline $\begin{array}{l}\text { Dismissed worker and } \\
\text { asked North Korean } \\
\text { partner to hire new one }\end{array}$ & 2 & $4 \%$ & 1 & $3 \%$ & 1 & $8 \%$ & 0 & $0 \%$ & 1 & $20 \%$ \\
\hline $\begin{array}{l}\text { Never hired an } \\
\text { unsatifactory worker }\end{array}$ & 13 & $28 \%$ & 7 & $21 \%$ & 6 & $46 \%$ & 4 & $50 \%$ & 4 & $80 \%$ \\
\hline
\end{tabular}

Note: Firms could choose all responses that apply. 
Figure 1.

Chinese luxury goods exports to North Korea, 2000 - 2014

Millions US\$

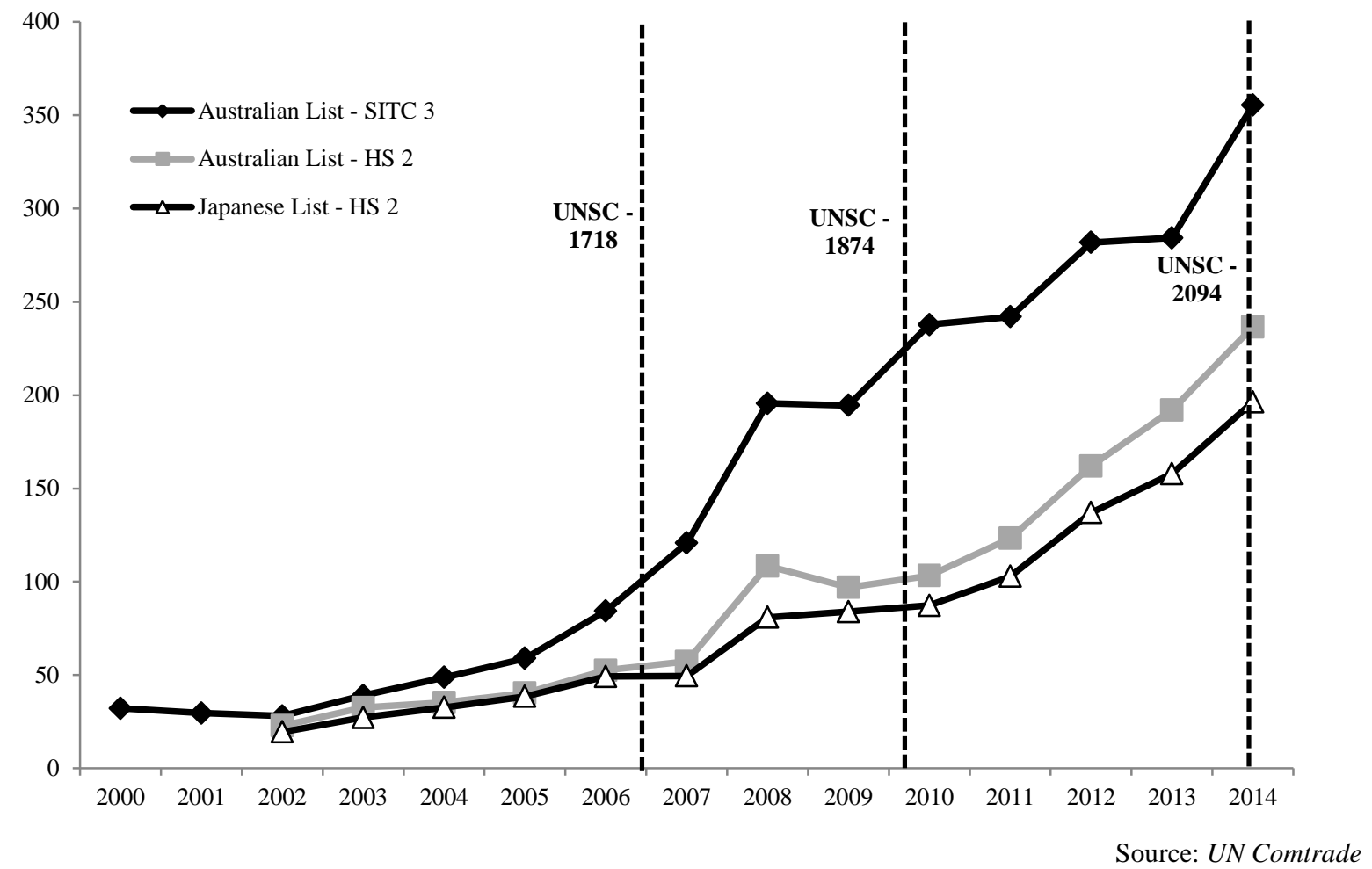

Figure 2.

North Korea's Year-To-Date Trade with China through July of Each Year

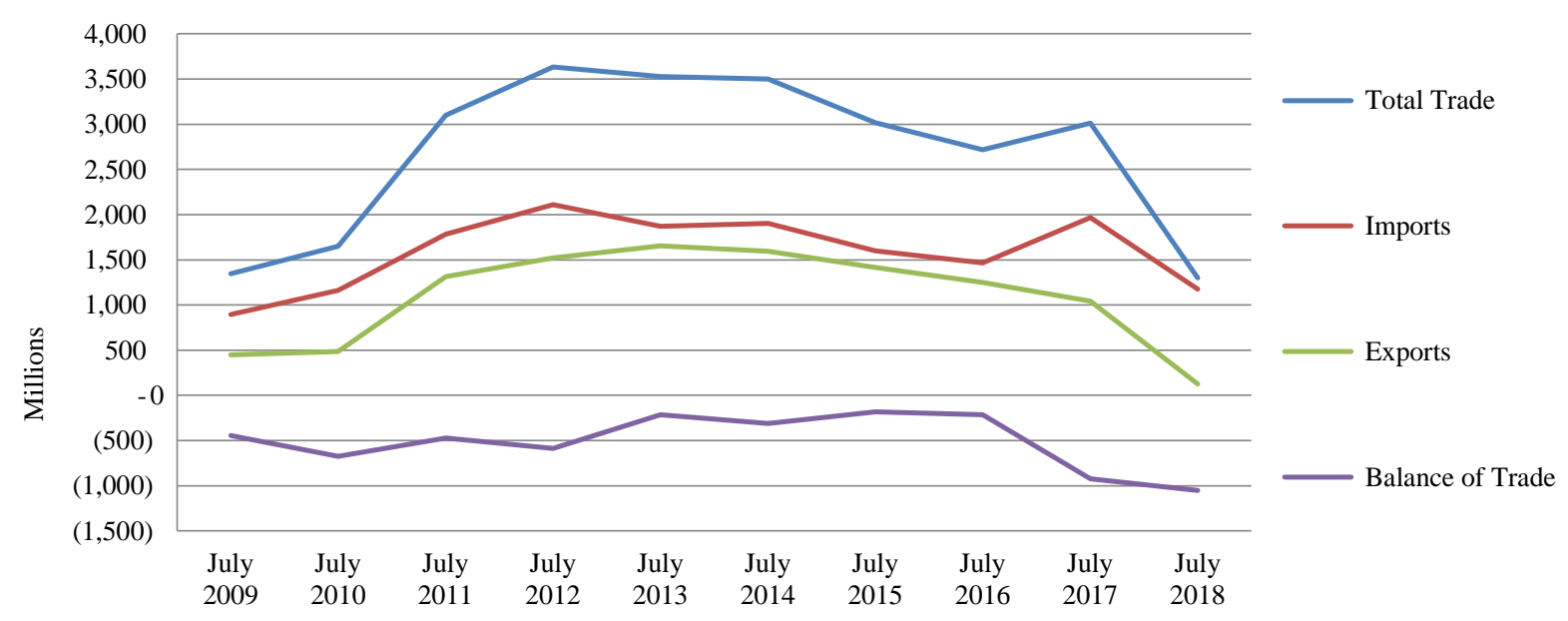

Source: China Customs (WIND) 
Figure 3.

US Dollar to North Korean Won and Rice Price

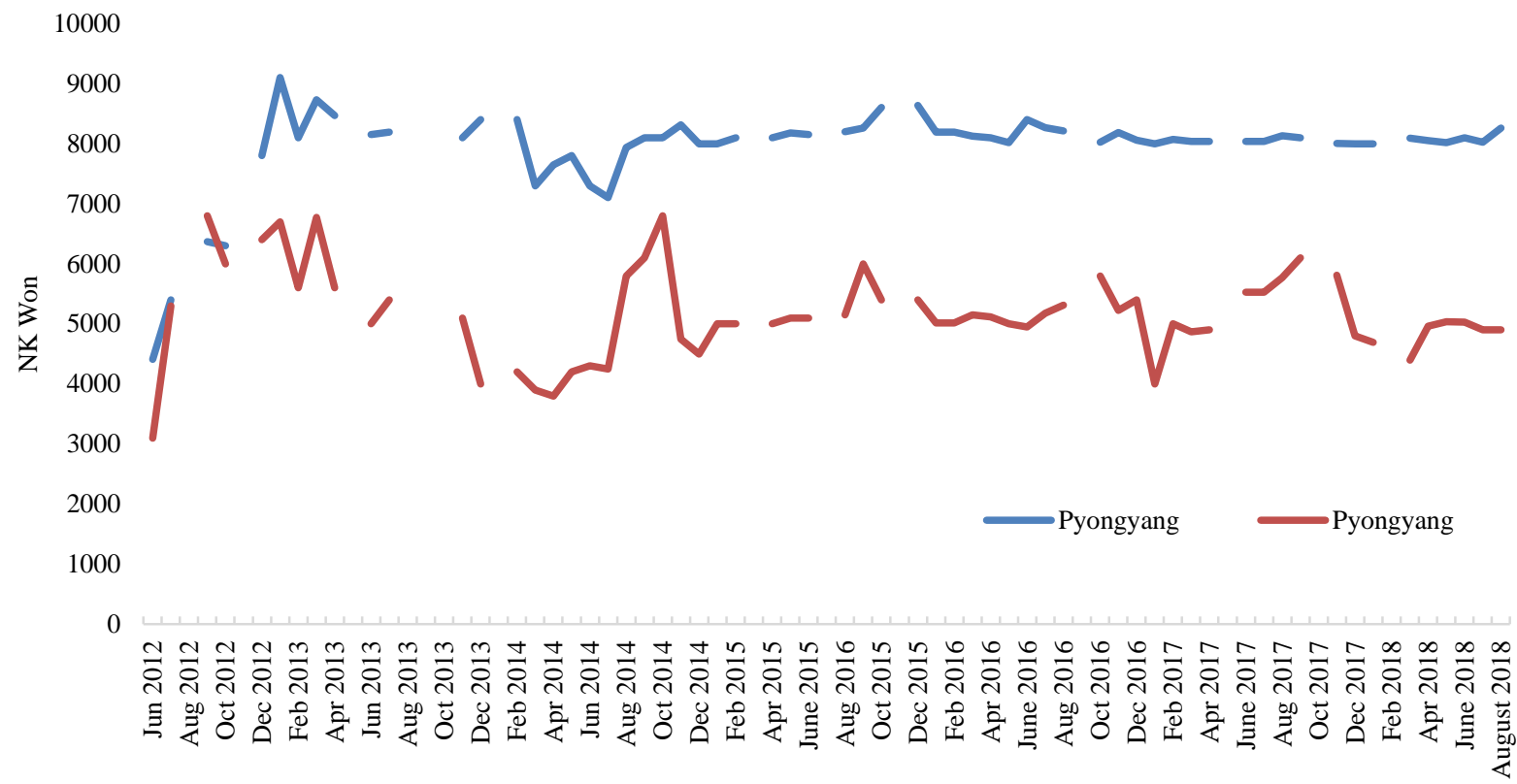

Source: Daily NK, Pyongyang black market rates

Figure 4.

Firm opinions on North Korean worker satisfaction

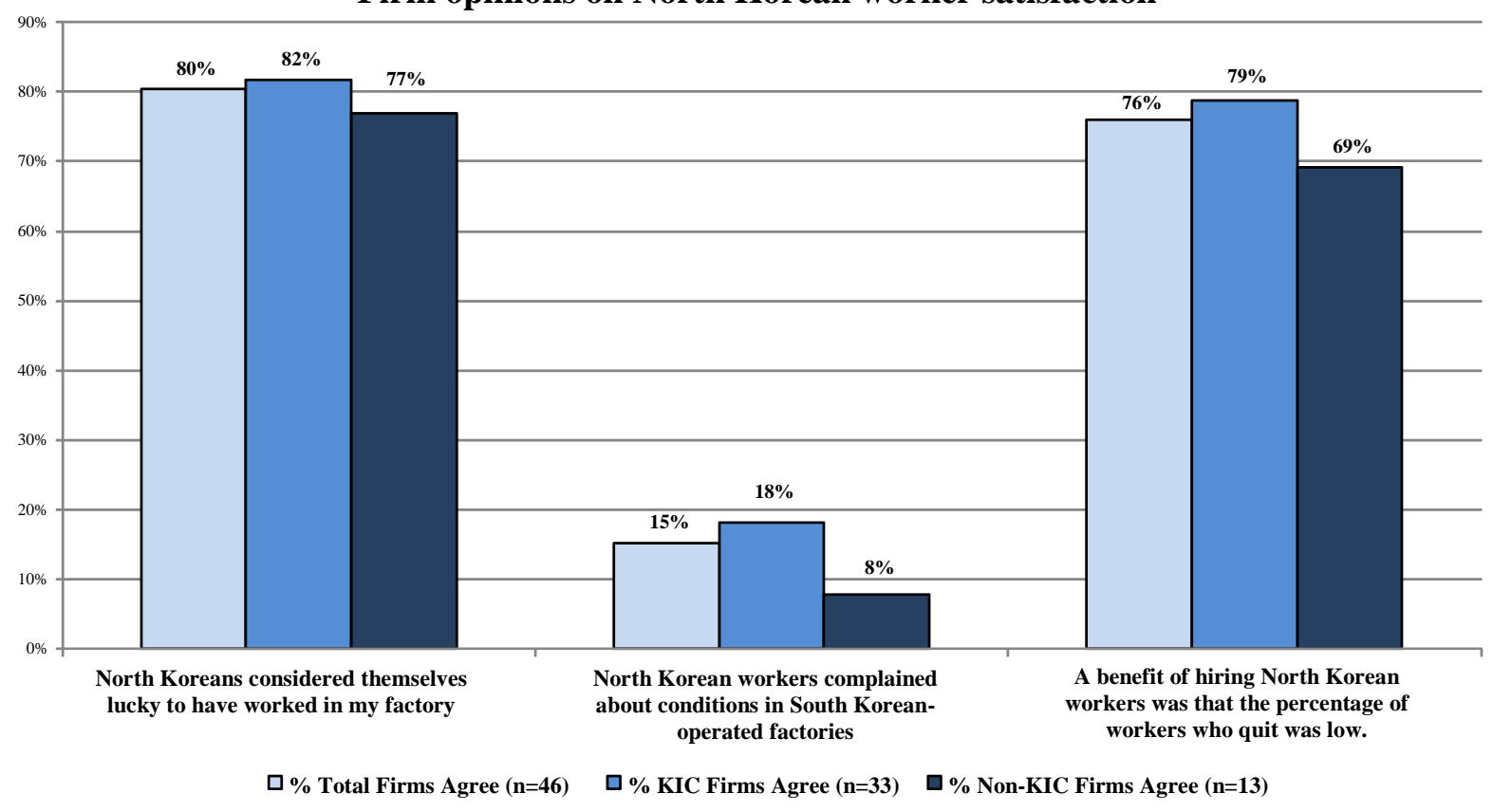

Note: Bars represent percent of firms out of subsample that responded positively to the corresponding survey question. Positive responses aggregate 'Agree" and "Totally agree." 


\section{References}

Collins, Robert. 2012. Marked for Life: Songbun North Korea's Social Classification System. Washington: Committee for Human Rights in North Korea.

Farole, Thomas. 2011. "Special Economic Zones: What Have We Learned?," Economic Premise No. 64. Washington: World Bank Poverty Reduction and Economic Management Network (PREM). September. http://siteresources.worldbank.org/INTPREMNET/Resources/EP64.pdf

Haggard, Stephan, Jennifer Lee, and Marcus Noland. 2012. Integration in the Absence of Institutions: China-North Korea Cross-Border Exchange. Journal of Asian Economics 23, no. 2: $130-45$.

Haggard, Stephan and Marcus Noland. 2012. The Microeconomics of North-South Korean Cross-Border Integration. International Economic Journal 26, no. 3: 407-430.

Haggard, Stephan, and Marcus Noland. 2017. Hard Target: Sanctions, Inducements, and the Case of North Korea. Stanford, CA: Stanford University Press.

Haggard, Stephan, and Marcus Noland. 2018. Networks, Trust, and Trade: The Microeconomics of China-North Korea Integration. Asian Economic Journal, forthcoming.

Hendrix, Cullen and Marcus Noland. 2014. Confronting the Curse: The Economics and Geopolitics of Natural Resource Governance. Washington: Peterson Institute for International Economics.

Hufbauer, Gary R., Jeffrey J. Schott, Kimberly Ann Elliott, and Barbara Oegg. 2008. Economic Sanctions Reconsidered, third edition. Washington: Peterson Institute for International Economics.

McCrudden, Christopher. 1999. "Human Rights Codes for Transnational Corporations: What Can the Sullivan and MacBride Principles Tell Us?," Oxford Journal of Legal Studies 19:2 167201.

Noland, Marcus. 2014. "A Study to Analyze Cost-Benefits of the Reunification of Korean Peninsula to the United States," Long-term Trade Strategies Series, 14-01. Seoul: Korea Institute for International Economic Policy (KIEP).

OECD, 2011. OECD Guidelines for Multinational Enterprises. Paris: OECD.

Ra, Jong-Yil. 2013. "Living With Two Nations Under One Roof.” 38 North, January 7. https://www.38north.org/2013/01/jyra010713/ Accessed 20 July 2018.

Sethi, S. Prakash, and Oliver F. Williams. 2000. "Creating and Implementing Global Codes of Conduct: An Assessment of the Sullivan Principles as a Role Model for Developing International 
Codes of Conduct —Lessons Learned and Unlearned," Business and Society Review. 105:2. 169200.

Song, Yeongkwan. 2011. “KORUS FTA vs. Korea-EU FTA: Why the Differences?," KEI Academic Paper Series, 6 no. 5 http://www.keia.org/sites/default/files/publications/song_final_paper.pdf accessed 2 August 2018.

United Nations, 2011. Guiding Principles on Business and Human Rights: Implementing the United Nations "Protect, Respect and Remedy" Framework. http://www.businesshumanrights.org/media/documents/ruggie/ruggie-guiding-principles-21-mar-2011.pdf Accessed 7 November 2013.

Wolman, Andrew. 2010. "Addressing Labor Rights Abuses at Overseas Korean Companies: the Role of the North Korean State," Journal of Korean Law. Vol. 9 173-200.

Wolman, Andrew. 2013. "South Korea's Response to Human Rights Abuses in North Korea: An Analysis of Policy Options," Asia Pacific Issues No. 110. Honolulu: East-West Center.

Zang, Hyoung-soo. 2013. "Estimation of and Analysis on the Balance of Foreign Exchanges of North Korea for 1991-2012," Unification Policy Studies 22, no. 2: 165-190. 